\title{
Race and Race Equality: Whiteness in Initial Teacher Education
}

\author{
Christine Callender
}

\section{Introduction}

There is a paucity of research concerned with teacher educators' perspectives and understandings of race and race equality in initial teacher education (ITE) in England. Th is issue is particularly signifi cant given the current shift towards a school-led workforce development model in which schools are increasingly responsible for training newly qualifi ed teachers (NQTs), through, for example, School Centred Initial Teacher Education (SCITT), Teaching Schools, Schools' Direct and under the auspices of designated powers to award Qualifi ed Teacher Status (QTS). By focusing on the 'gatekeepers of the profession' (Wilkins and Lall, 2 011) - those with responsibility for strategically leading and managing teacher education courses - this chapter aims to disrupt the gaze of the extant literature to illuminate how initial teacher education is implicated in the production and maintenance of Whiteness and white privilege resulting in the perpetuation of hegemonic discourses about the participation of black, Asian and minority ethnic (BAME) students in ITE. Specifi cally, whiteness is considered in the context of ITE by focusing on how senior leaders understand and practice race equality during a period of race salience.

A qualitative methodology utilizing semi-structured interviews with university-based ITE course leaders across England was adopted and asks two main questions: (1) What do teacher educators understand by race and race equality; (2) How do these understandings infl uence the ways in which they work with and for race and race equality? Drawing on data collected in 2006, the chapter illuminates how, despite the legal requirement to promote race equality, institutional practices did not achieve their intended aims. This has signifi cance not just for BAME students in ITE but also for the ways in which discussions of race are erased and/or censured from the early training 
experiences of beginner teachers. By locating the research in its historical moment and through making connections to its contemporary context, the chapter illustrates that, in the midst of a national eff orts in the ITE sector to increase the number of BAME students, the underlying ideological perspectives of teacher educators were nonetheless imbued with the 'Tools of Whiteness' (Picower, 2 009) . It highlights how in a period of heightened race awareness, where there was a national focus on greater representation of BAME teachers in the form of diversity targets, teacher educators maintained dominant racial hierarchies through the deployment of these tools. At the historical point of relative convergence, teacher educators, whilst sensitized to race equality, espoused a commitment whilst systematically resisting notions of privilege and power. Contemporarily, the chapter points to the recent marketization of ITE and the proliferation of teacher training routes which emphasized 'teacher quality', with the inevitable, concomitant eff ect being that those entering the profession oft en do so without the opportunity to examine their own prejudices or assumptions. Fundamentally, the chapter argues that there has been little change.

In the current moment race has been erased and silenced, replaced instead by a discourse of meritocracy where only 'the brightest and the best' are selected for ITE programmes. Moreover, changes to race equality legislation which now combine race equality under the broader remit of equalities has, in eff ect, diluted the focus on race overall. An emphasis on teacher quality under the guise of meritocracy has led to fewer BAME entrants to ITE overall in recent years and the creating of what can be described as a 'mirrortocracy'. In the post-racial era, race is seemingly historicized, a non-existent factor in contemporary discourse where its relevance is questioned despite the racial disparities that exist at various levels of society.

\section{Th e issue in context}

Despite research into the experience of BAME students entering education, there is little critical analysis of the work of teacher educators related to race and racism in England. Th is is not just a feature of teacher education. In fact, it can be argued that the higher education sector has struggled to get to grips with the diff erential degree outcomes of BAME students and the small 
proportion of students gaining access to Russell Group institutions (Boliver, 2 016). These concerns are long-standing, operating as the metaphorical elephant in the room:

Higher education has a dirty little secret: white students get more fi rsts and $2: 1$ s than black students - and no one even talks about it $[\ldots]$ we don't know why this is but we should certainly talk and disagree about it. (Cited in Reisz, 2012 )

Several writers report that universities have failed to deliver on race equality (Curtis, 2000; John, 2 003; Pilkington, 2 009, 2 011; Reisz, 2011), despite the legal duty to promote it. According to Back (2 004), the higher education sector in England remains 'hideously white' both in terms of its student body and its staff. Writing later, Pilkington (2 011) reports that higher education institutions (HEIs) are 'oblivious to inequalities in our midst and the need to ensure that our policies and procedures are evidence based'. Whilst Miller (2 016) draws attention to the ways in which racial inequality has impacted upon the recruitment, selection and promotion of BME staff in HEIs and other education settings.

More recently, Bhopal ( 2018 : 93) has argued that 'racism and racist practices dominate the experiences of black and minority students in higher education'. In an analysis of white privilege in the United Kingdom and United States, Bhopal asserts that:

' elite universities are the epitome of the legitimation and reproduction of institutional racism. Th ey continue to play their part in the reproduction and reinforcement of racial and class inequalities. In this system of exclusion, black and minority ethnic students remain marginalised and excluded. Higher education institutions are spaces of white privilege which fail to cater for the experiences of black and minority groups. Th ey employ a rhetoric of inclusion, but one that is rarely evidenced in practice or outcomes'. (103)

Bhopal makes an important distinction between acceptable and nonacceptable forms of whiteness, and in so doing illuminates the ways in which class, whiteness and white privilege intersect in powerful ways:

' Acceptable forms are those which are marked at the intersection of class, whiteness and white privilege whereas unacceptable forms can be located in the identities of Gypsy and Traveller groups, expressed through 'a racism that is acceptable towards an unacceptable form of whiteness'. (157) 
The performance of whiteness speaks the rhetoric of inclusion whilst simultaneously practising exclusion. Applebaum (2010: 9) asserts that 18

' while the defi nition of whiteness is diffi cult to pin down, there is widespread agreement that whiteness is a socially constructed category that is normalized within a system of privilege'.

She cites the work of Ruth Frankenberg, who defi nes whiteness as:

' a location of structural advantage, of race privilege. Second it is a 'standpoint', a place from which White people look at ourselves, at others, and at society. Th ird, 'Whiteness' refers to a set of cultural practices that are usually unmarked and unnamed'. (9)

Whiteness thus operates in diff erent ways. It is unmarked, unrecognized and not consciously acknowledged. At one level whiteness, as Penny McKintosh argues, is the sum of an invisible knapsack of privilege - unearned and unseen by its benefi ciaries. Leonardo ( 2004 : 148), on the other hand, states,

' whites enjoy privileges largely because they have created a system of domination under which they can thrive as a group. Th e volumes of writing on the issue of domination testify that the process is complex and multi-causal. But the enactment is quite simple: set up a system that benefi ts the group, mystify the system, remove the agents of actions from discourse, and when interrogated about it, stifl e the discussion with inane comments about the "reality" of the charges being made'.

For Hick et al. ( 2011 : 18), ITE is a key starting point for examining race, noting that there 'remains the need to recognize the reality and persistence of racism in education'. It is important to acknowledge that a number of studies examine the experiences of BAME students in ITE and in teaching in the United Kingdom (McNamara et al., 2010 ; Carrington et al., 2001; Osler, 1997 ; Showunmi and Constantine-Simms, 1995 ). Th emes to emerge from this literature include BAME student experience, strategies to improve participation through recruitment and retention and experiences of racism. It is not the purpose to examine these here but instead to use these to emphasize the invisibility of teacher educators' perspectives and understandings of race in ITE - teacher educators are largely seen in relation to work undertaken in the pedagogical areas of equality and diversity, whilst conversations about race are projected upon BAME bodies or narrated in relation to student experiences. 
Few studies in the United Kingdom have explored the perspective of teacher educators, particularly those with responsibility for leadership and management of ITE courses and curricula. Where teacher educators' views are sought, research has concluded that, although teacher educators are well versed in race equality issues, they may not be well placed to bring about change within their institutions, suggesting 'there is a need for greater knowledge of teacher educators' understanding of issues of race; and how race and race equality are embedded into teacher education' (Hick et al., 2 011: 6). Hick et al. make an important observation that not only speaks to the application of knowledge of race but also to teacher educators' personal understanding/experience of race - a factor that has had little empirical coverage in the literature. Bhopal, Harris and Rhamie (2 009) make a similar point, albeit more explicitly, noting that teacher educators play a pivotal role in disrupting normative assumptions of race but may lack knowledge and expertise in these issues (see also Galman, Pica-Smith and Rosenberger, 2010 ). Th e signifi cance of teacher educators is highlighted by Ryan and Dixson ( 2006 : 181), who also refer to the critical role of teacher educators' pedagogy in shaping their own and their student's understanding of race in the United States. Similarly, Bhopal and Rhamie (2 013) point to the need for increased practical support and training for beginner teachers in order to improve understanding of and responses to issues of race in the classroom.

Maylor ( $2014: 178$ ) has also commented on the role of teacher educators and the critical role they play in ensuring that beginner teachers develop an understanding of race and racism, arguing that they should be aff orded opportunities to examine their own attitudes and assumptions:

If pre-service teachers are to become more critically aware of the limited parameters of their thinking Johnson, Lachuk and Mosley suggest that teacher educators should engage pre-service teachers in 'continual opportunities for dialogue and storytelling' (2012: 327, cited in Maylor 2014) about themselves, their internalised ideologies, the infl uence of White privilege and power and issues concerning 'race' and racism (including their own; King, 2007).

The practical task of engaging in critical conversations about race, however, is far more complex. Discussions of race in ITE are oft en regarded as 'scary' and met with a deafening silence or are derailed (Lander, 2 011). Picower (2009), describing the strategies used by predominantly white students to avoid (or evade) engagement in conversations and/or explorations about race 
and racism, refers to this practice as the 'tools of whiteness'. In her study of pre-service teachers, she states that

' participants responded to challenges to these understandings by relying on a set of 'tools of Whiteness' designed to protect and maintain dominant and stereotypical understandings of race - tools that were emotional, ideological, and performative'. (197)

20

The 'tools' support the maintenance of hegemonic stories and are comprised of three types. Picower describes these as emotional tools, which are based on feelings and function so as to 'obfuscate the concepts being introduced'; ideological tools, which represent beliefs that protect hegemonic stories; and performative tools of whiteness, which relate to behaviours that are consistent with hegemonic understandings.

\section{Th e study (methodology and design)}

The present study draws on interviews which examine race from the perspective of the 'gatekeepers of the profession' (Wilkins and Lall, 2011 ) - those with responsibility for strategically managing teacher education courses. By focusing on teacher educators' practice, it disrupts the gaze of the extant literature in the United Kingdom on race/race equality in ITE and illuminates how Whiteness is deployed to perpetuate hegemonic (and oft en negatively oriented) discourses about race/racism. In the words of Leonardo (2 009: 107), this chapter attempts to 'make race visible' by 'making whiteness visible'.

The original study (Callender, Robinson and Robertson, 2006) set out to understand teacher educators' understandings of race and the ways in which this infl uenced their approach to the programmatic functions of ITE. It was particularly interested in how these actions impacted upon the outcomes of BAME students. Th e study evaluated the extent to which the institutions explicitly undertook monitoring and tracking of various aspects of ITE provision (e.g. recruitment and retention, academic performance, practicebased aspects of training and appointment to a teaching post) but also drew on interview data with programme and course leaders. It is the latter which is the focus of this chapter. Th e research is conducted within an interpretative 
paradigm and employs critical race theory (CRT) as an analytical lens. Participating institutions were drawn from universities across England. Collectively, the institutions diff ered greatly in terms of demography. Initially, twenty HEIs were invited to participate, of these ten were included in phase one of the study. In phase two this was reduced to six as four of the institutions withdrew due to Offi ce for Standards in Education, Children Services and Skills (Ofsted) inspections. In each institution the key members of staff with strategic responsibility for leading the ITE provision were interviewed (comprising a total of nine participants altogether as in some institutions more than one person was present for interview). Data from a sample of three institutions and three participants are reported here to contextualize the

discussion and to illuminate the issues as they perceived and experienced in the institutional setting. Whilst there is a level of selection in the presentation of findings, the institutions have been chosen due to their profiles (Russell Group and post-1992 universities) and different geographical locations (one in an inner city, another in an affluent university town and the other in a shire community). Th e names of institutions have been changed to assure their anonymity and that of staff. A brief outline of each institution is presented below:

Yewtree University is on the outskirts of a vibrant multi-ethnic city. It prides itself on its reputation for widening the participation agenda and has a history of attracting higher than average numbers of minority students. Acorn University is located in an affluent, predominantly white university town. It has a national and international reputation of academic excellence. Oak University is located in a former industrial city which has undergone extensive regeneration. Th e student body is mainly white and drawn from a wide geographical area. In recent years it has seen growth in its international student cohort. Th e university has several outreach projects aimed at local communities. All geographical references which might identify the locations of the institutions have been altered.

Data were collected in two phases. First, questionnaires which elicited contextual information such as ethnicity and achievement data, student profiles, retention, withdrawal, failure and success rates, achievements and challenges and any actions to support equality and diversity work were 
completed. Second, face-to-face semi-structured interviews of senior ITE staff with leadership and/ or management responsibilities were conducted. Interviews were digitally recorded and verbatim transcripts were returned to participants to check for accuracy prior to analysis. Thematic analysis (Braun and Clarke, 2 006) was used to organize data into themes. Additionally data triangulation supported the identification of similarities and differences in the practices of teacher educators.

CRT is used as a lens through which to examine the ways in which teacher educators understand and practice race equality. Th e antecedents of CRT can be located in the field of critical legal studies in the United States. Its use, however, has subsequently been applied to education in the United Kingdom (Chakrabarty, Roberts and Preston, 2012; Gillborn, 2005, 2006, 2013, 2014, 2015 ; Hylton, 2012; Rollock, 2012 ; Warmington, 2012 ). Underlying CRT is the premise that racism is not an anomaly but a historical legacy and continuing process of the subordination of people of colour. In this sense racism is normal and mundane within society. CRT is deployed here to foreground the salience of race in teacher educators' practice. At its core is the contention that racism

22

is endemic, institutional and systemic - it is normal, ordinary, not abhorrent and integral to the way in which society works (Bell, 1 992; Solórzano and Delgado Bernal, 2001). CRT analysis provides a framework for a raceconscious examination of structural racism. It does not set out to find answers but instead exposes issues, revealing the overt and covert ways that racist ideology, structures and institutions create and maintain racial inequality. As such, it is a helpful tool with which to examine questions of epistemology, knowledge production and dissemination. CRT critically examines master (or dominant) narratives that are reproduced and the counter-narratives that are silenced. Based on five key tenets, CRT focuses upon the centrality and intersectionality of race and racism; the challenge to dominant ideology; a commitment to social justice; the centrality of experiential knowledge and the interdisciplinary perspective. It is not my intention to rehearse the details of CRT here as these are examined elsewhere (Bell, 1 992; Crenshaw et al., 1 995; Taylor, Gillborn and Ladson-Billings, 2 009; Gillborn and LadsonBillings, 2 010) . Rather, it is my intention to reveal 'interest convergence', one of the tenets of CRT which highlights that teacher educators are central 
to maintaining the ways in which discussions of race and racism take place within ITE, and which illuminates whiteness and white privilege as a lens through which race and racism are understood and practised. The underlying premise of interest convergence is that race equality is only advanced when the interests, expectations and ideologies of Whites converge with those from minoritized groups. A key aspect is the notion of loss and gain, where one group (usually the dominant one) has to give up something or negotiate for the interests of both groups to converge. In this case, the research was undertaken in the period after publication of the McPherson Report and where changes to legislation impacted upon the race equality practice of all public bodies, including universities, and where the requirement to promote race equality and to take active steps to reduce racial discrimination were codified in law. The duties under the Race Relations (Amendment Act) also meant that institutional data had to be publicly available for scrutiny. With regard to ITE, an additional accountability measure in the form of diversity targets from the then-Training and Development Agency ${ }^{1}$ (TDA) meant that all universities were expected to take proactive steps to recruit BAME students, all of which would contribute to a national target. In short, if universities recruited at or above target and/ or could demonstrate that they were engaged in activities designed to improve the recruitment and retention of BAME students, this information was used to benchmark race equality practice and used to improve a university's institutional capital.

Th e chapter thus illuminates how race is done by teacher educators and the slow pace at which change in practice takes place. In this sense, the use of CRT and interest convergence, in particular, exposes whiteness as a system of meaning about race, ethnicity, class and gender (Leonardo, 2009 ; BonillaSilva, 2010 ).

\section{Th e evidence}

All institutions involved in the study expressed a commitment to race equality. Th is was regarded as highly prized and as a measure of good standing within the audit and accountability framework within which teacher education in the United Kingdom took place at the time (i.e. the postMacPherson era). At this time externally set diversity targets aimed to 
increase the number of BAME students and played an integral role in either building upon or maintaining a commitment to widening participation and by implication reputational capital - the profit gained from engaging in 'diversity' work.

\section{'We've met our target'}

I t was not uncommon during interviews for the phrase 'we've met our target' to be invoked as evidence of good race equality outcomes or indeed practice. In many senses it was considered to have contributed to the reputational capital of institutions. Despite this, however, race equality was perceived as problematic and difficult - with the potential to lead to institutional losses (e.g. non-completions or high dropout and withdrawal rates). It was apparent that recruitment targets were seen as an external driver leading to institutional success and esteem. Universities had a vested interest in meeting diversity targets as it conferred enhanced status in the ITE sector and by implication (the universities) were more appealing to BAME student groups. HEIs who met the target were judged (and judged themselves) as not only being 'good' at recruitment and retention but also 'good' at race equality (Ahmed, 2007 ).

A corn University, a prestigious pre-1992 university with a global reputation for academic excellence, draws its student cohort from a monocultural, wealthy, mainly white student body. Due to its reputation of academic excellence and the fact that it attracts high-calibre students nationally and internationally, it does not regard diversity targets as integral to its ITE work. Its courses were often oversubscribed. Unlike Yewtree, its reputational capital is not based on its image as a diverse institution. It has struggled to recruit BAME students. Those who study at Acorn are academic high-flyers, most of whom go on to teach in the independent school sector. Acorn has focused eff orts on supporting those of exceptional ability who may not possess the financial resources to support their course of study. Class is a determining factor at Acorn, and it is vocal about its commitment to widening participation and recruiting the brightest students from schools in the state sector. Pilkington ( 2009 : 17) notes, 'there is little doubt that widening participation is primarily concerned with class'. Race has been a lesser concern amongst most institutions. Acorn's commitment was evidenced in the provision for students without the financial means to study. In terms of its ITE provision, it had undertaken a range of additional activities to raise aspirations and encourage applications from under-represented groups and 
had implemented initiatives with regard to race equality. For example, it worked with BAME alumni to promote teaching as a career; developed an information management system to monitor BAME student progress; and consulted with/ revised its schools partnership agreement to ensure a consistent approach to dealing with racist incidents. In response to a question about the low application rate of BAME students, the course leader commented,

'I just feel it's the image we have. Also we don't want to recruit more [BAME students] in some senses until we get sorted out. There's no point saying 'Oh great, we've met the target', that's the wrong way around. I mean targets are important because they are expressing a commitment [ . . ] but you get everyone on, they have a horrible experience and they never go into teaching'.

BAME students are perceived as somewhat problematic. They are bodies out of place, disorienting and disrupting the equilibrium of whiteness, or, as Puwar (2 004) puts it, they present dissonant bodies that take the form of 'space invaders' and 'aliens' in white spaces. Th e statement above additionally raises important questions about how a commitment to race equality is expressed. In this case it is by not recruiting BAME students until the institution is able to sort itself out or, in other words, through the production and maintenance of normative whiteness.

'Good' diversity practice was concealed within hidden institutional practices, attitudes and assumptions about race and race equality. For example, at Yewtree School of Education, although the number of BAME students is low, their completion rates are high - leading the course director to report, 'although recruitment of BAME students can be a challenge, we are pleased that we do meet the targets for recruitment of BAME students to ITT programmes'. The 'challenge' for Yewtree is worthy of continued investment as this is seen

to lead to good retention rates - a tool to measure institutional performance and an indicator of 'good' race equality practice. It also provides Yewtree with an opportunity to promote itself as a mainly white university committed to and proactive about race equality and to use this as a marketing strategy for future recruitment. Like other institutions in the study, Yewtree's race equality policy set out how it aimed to achieve its goals. Th ese documents were a key barometer of an institution's 'race' work and were often referenced during interviews. According to Prior (2 003) cited in Ahmed (2 
007: 591), documents may have a significant function in that 'the University is its documents rather than its buildings'. Documents can work in unique ways, moulding organizational structures and deciding what, how something gets done and why something gets done, or, as Ahmed notes, "the politics of diversity has become what we call "image management": diversity work is about generating the "right image", and correcting the wrong one'. Th us, with respect to race equality, it is concerned with 'changing perceptions of whiteness rather than changing the whiteness of organizations' (605). Deem and Morley (2 006: 196) make a similar point with regard to senior managers' views of diversity and equality being couched in 'well told stories' and that 'senior managers are institutionally placed to provide positive stories about institutional policies'. Th ese, they argue, play a pivotal role articulating and enacting key messages about institutional ethos and position:

'We're meeting the targets that we set for our ethnic minority numbers and are actually over them and our year one students are up as well in terms of that. It's not to be complacent. My focus is on keeping them here once we've got them and ensuring what we are doing is valid and relevant to them'. (Course Leader, Oak University)

Th us, in those institutions where there were high levels of student diversity, this was invoked as an indicator of success - doing well in race equality was inextricably tied to having a 'diverse' student body. Hey, Dunne and Aynsley (2 011: 4) observe that 'where student diversity has a strong marketing appeal there is a sense that diversity and equality has been achieved'. Th is would appear to be the case at Yewtree University, which prides itself on achieving success in recruiting significant numbers of students from diverse backgrounds:

For the last three years our retention, our recruitment has been very, very strong. We have had no problems this year. We didn't go into clearing this year, we didn't go into clearing the year before and we didn't take any borderline students this year. So obviously we'll see how things go. (Course Leader, Yewtree University) 26

It is interesting to note the initial confusion between recruitment and retention and its uncoupling from race. Th e strong recruitment process is, in effect, deracialized and bound up in notions of 'quality'. On the one hand, it is instructive to note that ethnic minority student numbers are presented as being outside of, separate from and an adjunct, fulfilling a diversity tick box 
exercise. In this instance, race takes on an ephemeral quality. It is a metaphor for success. In this education space, BAME students signify a form of reputational capital, strengthening Oak's position in the ITE marketplace and provides proof of its success in race equality - reaching the target is demonstrative of institutional success and of being good at 'doing' race equality (Ahmed, 2 007).

\section{(Un)doing race}

Diversity targets presented both a tangible way of demonstrating and a measurable way of doing race equality. Institutions were not always clear of the ways in which targets masked a different narrative of race or the student reality. For example, data provided prior to interview revealed a significantly higher attrition rate for some categories of BAME students at Oak University. Clarity was sought about one such group during interview:

Author: Please tell me if I've got this right. Three students that passed, four who failed, three that withdrew and four that transferred?

Course Leader: Something like that [ . . . ] Yes.

Course Leader: We've only recently had Ofsted [ . . . ] I was looking at those success rates and the Black Caribbean $21 \%$ you know and you look at it as numbers. It maybe doesn't [ . . . ] well it does. It's a disaster and clearly something we have to focus on in terms of understanding what is contributing to that. It's all well getting people in if you can't keep them. It seemed to us that there were a greater proportion of them who were failing to succeed.

Th e recent positive Ofsted outcome is seen as analogous to confirmation of good race equality practice despite the fact that the data at Oak revealed significant underlying issues with completion rates of particular BAME groups, especially those who were African Caribbean. Initial uncertainty (something like that, it maybe doesn't [ . . ] well it does) is replaced by the disaster that has evaded the gaze of the university itself and seemingly Ofsted too. It has remained quietly sleeping in Oak's institutional structures as the headline data indicates that recruitment and retention is good overall. Race, whilst visible in

institutional diversity discourse, is, at the same time, silent, unacknowledged and untroubling. In explaining the data a bipolar narrative emerges in the way 
that Oak understands and practices race equality. On the one hand, the course leader draws attention to good race equality practice (we are doing well in BAME recruitment) and on the other creates institutional stories about why some groups of students do not do as well as others:

I think a number of these students are Access students who have come through the Access to Teaching route. They're coming through as mature students who have other issues so the intensity of the course is contributing to the difficulties that they are having. Some of them are perhaps not adequately prepared for that jump from the Access course onto the undergraduate course.

BAME students are presented in the form of problematic stories whose function explains (and in some cases justifies) BAME student outcomes. Th ese narratives, like the discussion of recruitment and retention above, position BAME students as the arbiters of their own demise. BAME students comprised an undifferentiated homogenized mass with similar educational histories and associated 'problems'. Students were commodified, measured and benchmarked as steps toward race equality, yet race is simultaneously valourized as a positive institutional quality but also lamented upon as displayed by the disastrous consequences of a disproportionately high failure rate. Th e term 'Access student' acts as a synonym for all BAME bodies and is utilized to maintain an ideological assumption of student deficit. Picower's (2009) notion of the ideological tools of Whiteness are apposite here as a way of understanding how race and race equality are constructed and reconstructed, and of the operationalization of normative whiteness. Moreover, these tools further enable the course leader (and by implication the university) to reproduce hegemonic stories of BAME attainment and race, in addition to dominant ideologies that negate, ignore or tiptoe around the issues raised.

Acorn University, in contrast, is aware that it is perceived as elitist and somewhat out of reach for many BAME students. Its reputation as a white, privileged world-leading institution unaccustomed to difference is captured by the course director:

Obviously we are very white and we come over as being very middle class and if you look at our institution White English, White English, White English. White English everywhere.

Th e repetition of the phrase White English underscores the overwhelming weight of whiteness. It is omniscient and pervasive - it is everywhere, 
surrounding and engulfing the institution. Its global reputation in some ways protects it from the racialized other and discourses of race equality. It is a bastion of excellence with only the brightest and the best being afforded the opportunity to study there. At Acorn the pursuit of race equality is viewed as an external imposition, a mechanism for central government to ultimately make claims about the diversification of the teaching force:

I t's all about government ministers being able to stand up and say we've got so many black and ethnic minority students in recruitment then nobody is actually looking at what is actually happening.

This is evidence that the ideological tools of whiteness can be identified in the way that the course leader at Acorn perceives race and race equality as problematic, indicating that the education system more broadly is the reason why many BAME applicants do not apply:

I n Asian Pakistani groups you don't get many coming through because we know how the system disadvantages them so they never feel they could apply to Acorn for a start and then apply to a PGCE course here. Yes, that's one of the problems I think with minority ethnic recruitment that our education system disadvantages many minority ethnic students so they underachieve in the education system so they never get to degree level and then, you know [ ... ] become teachers.

As indicated earlier, the number of BAME students attending Russell Group institutions remains stubbornly low in England, whilst a preponderance of BAME students attend post-1992 institutions. Furthermore, recent research has shown that BAME students are more likely to have their application to university scrutinized as part of university admissions processes (Busby, 2 018) . Th e extract highlights an uncoupling from race - the presence of racialized bodies disrupts the whiteness of the institution and in so doing stymies discussions of race equality. On the one hand Acorn University wants to better prepare itself for minoritized students, but on the other hand it was attempting to manage the presence of a few BAME students on its courses. An area which appeared to cause concern was in the placement of students in local schools for school-based professional learning:

We are never really sure about this $[\ldots]$ to resist the temptation of they are Muslim and we'll send them to School X. They speak Urdu and Urdu is a subject at School X. But that's not what we should be doing. We should be making every 29 
single school that we send our students to an acceptable placement and not ghettoize if you like.

It was intriguing that the matching of beginner students to schools on the basis of cultural or religious affiliation was considered a viable option for school placement. Acorn is aware of the need to engage its partner schools so that the placement of a BAME student is not regarded as out of the ordinary or problematic but appeared at a loss as to how this was to be achieved. It became clear that matching was indeed considered an option when schools 'reacted' to the placement of minority students:

There is lots of poverty in XXXX, the schools are quite demographically different in terms of social class but not in terms of ethnicity at all. If you take one of the schools in XXXX you would think that you are in Tory land. It's nice. You've got XXXX, the school itself is a very interesting school because its predominately white students but there is a lot of poverty - farming, urban problems, very poor children go to that school. So it is very bipolar, very middle class and very poor agricultural working class. Schools are very interesting in this area, In some cases very white actually. If you send an Asian or black or minority ethnic teacher to one of those schools it does get commented upon and you will see from the comments [one the student report] [ . . ] although everyone has seen the report and we would have discussed it. But at the end of the day the students don't tell you. That's the issue they don't tell you. They don't rock the boat.

Th e extract above draws attention to the practice of normative whiteness and negative perceptions of race and class. Th e accepted forms of whiteness can be found in the schools in Tory land, whilst unacceptable whiteness is related to poverty, urban problems and very poor children. Th e racialized bodies of students, in contrast, interrupt the whiteness of both types of schools to the extent that it gets 'commented upon'. At Acorn University, race (and by implication race equality) is the responsibility of and belongs to the bodies of BAME students. Race is apparent when BAME students are placed in 'Tory land' or indeed 'interesting schools' that serve the urban poor. However, responsibility for dealing with racism is placed upon the BAME students themselves as 'they don't tell you' for fear of rocking the boat. Th e university is knowing yet unknowing, complicit and silent - engaging in what Leonardo (2 009: 113) refers to as white racial knowledge: 'knowing how the world works in racially meaningful ways, but avoiding to name it in these terms'. 


\section{Implications and conclusion}

Th e findings outlined above illustrate the ways in which race and racism are talked about, responded to and understood by course leaders at Yewtree, Oak and Acorn Universities. It is important to acknowledge here that this discussion set out to illuminate how a small number of course leaders at a specific point in time understood race and the ways in which they engaged in the doing of race. Th e findings therefore are intended to highlight practice and are not generalizable nor necessarily indicative of practices across all ITE provision. Th e deployment of CRT as an analytical lens has highlighted the ways in which race is ascribed as evidence of 'good' institutional race equality practice; inscribed on the bodies of BME students as other and problematic; used to reproduce ideological discourses of race and/or student experience of racism; and is significantly inextricably bound up with the ideological tools of whiteness. In addition to this it illustrates how the leaders of ITE provision understand and experience race as a distant out-of-body experience, disconnected from and unrelated to their own white racialized identities - and privilege - yet, at the same time, race is hypervisible, valued and problematic when it enters the white space of ITE. As Leonardo ( 2009 : 107) reminds us, knowledge about race and racism is known, and 'whites do know a lot about race in both its everyday sense as a lived experience and its structural sense as a system of privilege. In other words, it is imperative to "make race visible," with the specific goal of "making whiteness visible" '.

The 'Tools of Whiteness' provide a useful lens through which to examine teacher educators' unexamined assumptions and taken-for-granted notions. Th e 'tools' are the critical elements that bolster dominant ideologies such as white supremacy. They are essential to the sophistication of whiteness and its durability as a significant force. Like the beginner teachers in Picower's study, when teacher educators are challenged to think beyond their white normative ideologies, they draw on these tools to avoid, subvert and obfuscate conversations of race and race equality, highlighting that it is not passive resistance that is significant here but the active protection of dominant ideologies that pervade ITE.

At a time where there exists a range of ITE options in England, when the teacher workforce is becoming less reflective of the communities it serves and the student population is becoming more diverse, it is incumbent upon those with responsibility for leading and managing teacher education, regardless of 
the route to certification, to be far better equipped to understand how 'ordinary' everyday practice reinforces racism and reproduces whiteness. Hick et al.'s (2 011) and Bhopal and Rhamie's (2 013) observations are pertinent here as this study concurs with the view that teacher educators' personal racial biographies, awareness of race and racism as well as awareness of the ways in which normative whiteness is contingent to antiracist practice and inclusive praxis are critical to attaining race equality. In short, as O'Brien ( 2009 : 205) reminds us, 'the responsibility for tackling racism should not rest solely on the shoulders of teachers or "multicultural" teacher educators, it is quite simply the responsibility of every power player involved in all aspects of the system'.

Th e study also sheds light on how ITE institutions are implicated in forms of racialized myopia - recognizing race whilst simultaneously engaging colour-blind or colour-neutral practices - and that teacher educators are intricately bound up in these processes. BAME student cohort numbers provide some institutions with a rhetoric that enables them to laud their success of widening participation, which is also sometimes seen as being equivalent to a commitment to 'good' race equality practice. Th e day-to-day experience of BAME students, however, regardless of institution and schoolbased professional learning, is de-racialized. Race occurs and is worn on the bodies of BAME students. It is embedded in their academic credentials and problematic in their allocation to school placement as well as their experience of it. For the teacher educators at Oak, Acorn and Yewtree, race and racism are understood as stories of problematized others. As Leonardo argues, 'white educators' epistemological framework is not determined [author's emphasis] by their whiteness' (109); rather, they see race through a different lens, that of white racial knowledge. In the context of the study, it is important to recognize that the interviews were conducted at a time when there was a legal duty to promote race equality, and that the course leaders were therefore more sensitized to discussions of race and racism. In the same way that it is incumbent upon beginner teachers to engage with and understand their own racial identities, it is critically important that those who are responsible for educating beginner teachers subject themselves to similar levels of self examination, not least because to do so is to subject one's unexamined assumptions to scrutiny. Yet the discussion above raises questions about the extent to which teacher educators proactively position themselves as change agents who advocate for race equality or whether they 
are compliant, collude with or are complicit in reproducing normative whiteness.

\section{Note}

1 Th e TDA was established in 2005 as a body responsible for the initial and inservice training of teachers and other school staff in England.

\section{References}

Ahmed, S. ( 2007 ), " "You End Up Doing the Document Rather Th an the Doing”: Diversity, Race Equality and the Politics of Documentation', Ethnic and Racial Studies , 30 ( 4 ): 590-609.

Ahmed, S. ( 2009 ), ' Embodying Diversity: Problems and Paradoxes for Black Feminists ', Race Ethnicity and Education, 12 ( 1 ): 41-52 .

A hmed, S.(2 012), On Being Included: Racism and Diversity in Institutional Life, D urham, NC: D uke University Press.

Back, L. ( 2004 ), 'Ivory Towers? Th e Academy and Racism', in I . L aw, D . P hillips, and L . T urney (eds), Institutional Racism in Higher Education, 1-13, Stoke on Trent: Trentham Books .

Bell, D. ( 1992 ), Faces at the Bottom of the Well: The Permanence of Racism , New York: Basic Books.

Bhopal, K. ( 2018 ), White Privilege: The Myth of a Post-Racial Society, B ristol: P olicy Press.

Bhopal, K . and J . R hamie. (2 013), 'I nitial Teacher Training: Understanding "Race", Diversity and Inclusion ', Race Ethnicity and Education , 17 ( 3 ): 304-25.

hopal, K .,B R R . H arris and J . R hamie (2 009), The Teaching of 'Race' Diversity and Inclusion on PGCE Courses: A Case Study Analysis of University of Southampton, Report for Multiverse .

B oliver, V . (2 016), 'E xploring Ethnic Inequalities in Admission to Russell Group Universities ', Sociology, 50 ( 2 ): 247-66.

Bonilla-Silva , E. ( 2010 ), Racism without Racists: Colour-Blind Racism \& Racial

Inequality in Contemporary America, 3rd edn, Plymouth, UK : Rowman \& Littlefi eld.

B raun, V . and V . C larke. (2 008), 'U sing Th ematic Analysis in Psychology', Qualitative Research in Psychology, 3 ( 2 ): 77-101. 
Busby, E. ( 2018 ), 'Black People in UK 21 Times More Likely to Have University

Applications Investigated, Figures Show', Th e Independent, 23 April. Last $\begin{array}{lllll}\text { accessed: } & 1 & \text { May } & 2018 & \mathrm{~h}\end{array}$ ttps://www.independent.co.uk/news/education/education-news/ uk-blackstudents-university-applications-investigation-more-likely-ucas-fi guresnuslabour-a8314496.html

C arrington, B ., A . B onnet, J . D emaine, I . H all, A . N yak, G . S hort and C. Skelton (2 001), Ethnicity and the Professionalisation of Teachers. Report to the Training Agency, L ondon: T eacher Training Agency.

Chakrabarty, N., L. Roberts and J. Preston . (2012 ), 'Editorial: Critical Race Th eory in England', Race, Ethnicity and Education, 15 ( 3 ): 1-3.

Crenshaw, K. , N. Gotanda, G. Peller and K. Th omas, eds ( 1995 ), Critical Race

Th eory: The Key Writings Th at Formed the Movement, New York: The New Press .

Curtis , P. ( 2002 ), 'Universities 'Panicking” over Race Act', The Guardian, 25 June.

Deem, R. and L. Morley ( 2006 ), ' Diversity in the Academy/Staff Perceptions of Equality Policies in Six Contemporary Higher Education Institutions ', Policy Futures in Education, 4 ( 2 ): 185-202.

Department for Education ( 2016 ), School Workforce in England, November. Last accessed: $25 \quad$ July 2018 https://www.gov.uk/government/uploads/system/uploads/ attachment_data/fi le/620825/SFR25_2017_MainText.pdf

G alman, S ., C . P ica-Smith and C . R osenberger (2 010), 'A ggressive and Tender Navigations: Teacher Educators Confront Whiteness in Th eir Practice', Journal of Teacher Education, 61 ( 3 ): 225-36.

G illborn, D . (2 005), 'E ducation Policy As an Act of White Supremacy: Whiteness, Critical Race Th eory and Education Reform ', Journal of Education Policy, 20 ( 4 ): 485-505.

G illborn, D . (2 006), 'C ritical Race Th eory and Education: Racism and AntiRacism in Educational Th eory and Praxis', Discourse: Studies in the Cultural Politics of Education, 27 ( 1 ): 11-32.

G illborn, D . (2 013), 'I nterest-Divergence and the Colour of Cutbacks: Race, Recession and the Undeclared War on Black Children', Discourse: Studies in the Cultural Politics of Education, 34 ( 4 ): 477-91 .

G illborn, D . (2 014), 'R acism as Policy: A Critical Race Analysis of Education Reforms in the United States and England', The Educational Forum, 78 ( 1 ): 26-41. 
G illborn, D . (2 015), 'I ntersectionality, Critical Race Th eory, and the Primacy of Racism:

Race, Class, Gender, and Disability in Education', Qualitative Inquiry , 21 ( 3 ): 277-87 .

Gillborn, D . and G . L adson-Billings (2 010), 'C ritical Race Th eory' , in P.

Peterson, E.

B aker and B . M cGraw (eds), International Encyclopedia of Education, vol. 6

: 341-47. Oxford: Elsevier

Hey, V., M. Dunne and A. Aynsley ( 2011 ), The Experience of Black and

Minority Ethnic Staff in Higher Education in England, L ondon: E quality

Challenge Unit.

Hick, P ., R . A rshad, L. M itchell, D . W att and L . R oberts (2 011),

Promoting Cohesion,

Challenging Expectations: Educating the Teachers of Tomorrow for Race

Equality and Diversity in 21st Century Schools, Teacher Educators for the 21st century : Grant Project Final Report. Escalate, Manchester.

H ylton, K . (2 012), 'T alk Th e Talk, Walk the Walk: Defi ning Critical Race Th eory in Research', Race Ethnicity and Education, 15 ( 1 ): 23-41.

John, G. ( 2003 ), Review of Race Equality Action Plans in HEFCE funded Higher Education Institutions. Last accessed: 1 May 2018, https://www.hefcw.ac.uk/ documents/publications/circulars/circulars_2007/W0740HE\%20circ.pdf 34

L ander, V . (2 011), 'R ace, Culture and All Th at: An Exploration of the Perspectives Of White Secondary Student Teachers about Race Equality Issues in Th eir Initial Teacher Education', Race Ethnicity and Education , 14 ( 3 ): 351-64.

Leonardo , Z. ( 2004 ), ' Th e Color of Supremacy: Beyond the Discourse of

"White Privilege "”, Educational Philosophy and Th eory, 36 ( 2 ): 137-52.

Leonardo, Z. ( 2009 ), Race, Whiteness and Education, Oxon : Routledge .

Maylor, U. ( 2014 ), Teacher Training and the Education of Black Children:

Bringing Color into Diff erence, O xon: R outledge.

McNamara, O., J. Howson, H. Gunter and A. Fryers ( 2010 ), The Leadership Aspirations and Careers of Black and Minority Ethnic Teachers. NASUWT and the National

College for Leadership of Schools and Children's Services, Birmingham : NASUWT . iller, P.M (2 016), 'White Sanction', Institutional, Group and Individual Interaction in the Promotion and Progression of Black and Minority Ethnic Academics and Teachers in England', Power and Education , 8 ( 3 ): 205-21.

O 'Brien, J . (2 009) , 'I nstitutional Racism and Anti-racism in Teacher Education: Perspectives of Teacher Educators', Irish Educational Studies , 28 ( 2 ): 193-207. 
Osler, A. ( 1997 ), Th e Education and Careers of Black Teachers: Changing Identities, Changing Lives B, uckingham, UK: O pen University Press.

Picower, B. ( 2009 ), ' Th e Unexamined Whiteness of Teaching: How White Teachers Maintain and Enact Dominant Racial Ideologies', Race Ethnicity and Education , 12 ( 2 ): 197-215.

Pilkington. A. ( 2009 ), ‘ Th e Impact of Government Initiatives in Promoting Racial

Equality in Higher Education: A Case Study', Ethnicity and Race in a Changing

World, 1 ( 2 ): 15-25.

Pilkington. A. ( 2011 ), Institutional Racism in the Academy: A Case Study, Trentham : Stoke on Trent.

Prior , L. ( 2003 ), Using Documents in Social Research: Introducing Qualitative Methods , L ondon: SAGE.

Puwar, ( 2004 ), Space Invaders: Race, Gender and Bodies Out of Place ,

Oxford : Berg.

R eisz, M . (2 012), 'Racial Divide Is Higher Education's "Dirty Secret” '. Last accessed: 30 April 2018, h ttps://www.timeshighereducation.com/racial-divideis-highereducations-dirty-secret/422140.article

R ollock, N . (2 012), 'Th e Invisibility of Race: Intersectional Refl ections on the Liminal Space of Alterity', Race Ethnicity and Education, Special Issue:

Critical Race Th eory in England, 15 ( 1 ): 65-84.

R yan, C . and D ixson, A . (2 006), 'R ethinking Pedagogy to Re-Center Race: Some Refl ections ', Language Arts, 84 ( 2 ): 175-83.

Showunmi, V. and D. Constantine-Simms, eds ( 1995 ), Teachers for the Future , Trentha: Stoke on Trent.

Soló r zano, D . and D . D elgado Bernal (2 001), 'C ritical Race Th eory, Transformational Resistance and Social Justice: Chicana and Chicano students in an Urban Context', Urban Education, 36 : 308-42.

T aylor, E., D . G illborn and G . L adson-Billings, eds (2 009),

Foundations of Critical Race Th eory in Education, New York: Routledge .

W armington, P . (2 012), “ "A Tradition in Ceaseless Motion”: Critical Race Th eory and Black British Intellectual Spaces ', Race Ethnicity and Education , 15 ( 1 ): 5-21.

Wilkins, C . and R . L all (2 011) , “ "You've Got to Be Tough and I'm Trying": Black and Minority Ethnic Student Teachers' Experiences of Initial Teacher Education', Race, Ethnicity and Education, 14 ( 3 ): 365-86. 
Race and Race Equality 